\title{
Early prenatal diagnosis of conjoined twins: a case report
}

\author{
Soraia S. Cunha ${ }^{1 *}$, Rosália S. Coutada ${ }^{1}$, Ana R. Neiva ${ }^{1}$, Rosete Nogueira ${ }^{2}$
}

\begin{abstract}
${ }^{1}$ Department of Obstetrics and Gynecology, Local Health Unit of Alto Minho, Viana do Castelo, Portugal
${ }^{2}$ Department of Anatomic Pathology, Clinic Genetic Center (CGC Genetics), Porto, Portugal
\end{abstract}

Received: 20 October 2018

Accepted: 13 November 2018

\section{*Correspondence:}

Dr. Soraia S. Cunha,

E-mail: soraiacunha@hotmail.com

Copyright: ( $)$ the author(s), publisher and licensee Medip Academy. This is an open-access article distributed under the terms of the Creative Commons Attribution Non-Commercial License, which permits unrestricted non-commercial use, distribution, and reproduction in any medium, provided the original work is properly cited.

\begin{abstract}
Conjoined twins are a very rare complication of monochorionic monoamniotic pregnancies, associated with severe mortality and morbidity. Ultrasonography has made early diagnosis of conjoined twins possible, allowing prompt management and counselling of parents. The diagnosis should be suspected when monozygotic fetuses are shown to consistently hold the same fixed position relative to each other. The location and extent of fusion between the twins determine the potential for surgical separation and postnatal survival. The authors report a case of conjoined thoracoomphalopagus twins, diagnosed by ultrasonography at 10 weeks of gestation. Due to high complexity of fetal fusion, termination of pregnancy was performed upon patient's request.
\end{abstract}

Keywords: Conjoined twins, Prenatal diagnosis, Thoraco-omphalopagus, Ultrasonography

\section{INTRODUCTION}

Conjoined twins represent one of the rarest forms of twin gestation, estimated to occur in 1.5 per 100,000 births worldwide. ${ }^{1-4}$ In about $1 \%$ of monochorionic pregnancies, the twins are conjoined, probably resulting from relatively late attempts at cleavage on day 13 or later. ${ }^{1-5}$ Therefore, when there is a case of monochorionic monoamniotic pregnancy, the possibility of conjoined twins should always be kept in mind.

Ultrasonography plays the most important role in the diagnosis. In fact, prenatal ultrasound diagnosis has been described since 1974, and lately most of the cases are diagnosed early in pregnancy. ${ }^{6}$ The earliest reported case of thoracopagus twins in literature was in the $7^{\text {th }}$ week of pregnancy. ${ }^{4}$ Conjoined twins are classified based on the site of fusion. The most frequent type is thoracopagus, but mixed types are also possible.

Even though the degree and the location of fusion and the shared vital organs determine the prognosis of conjoined twins, they are associated with a high perinatal mortality rate, with an overall survival rate of $25 \%$. $^{2}$ Early prenatal diagnosis and assessment is crucial to counsel parents for their informed decision, so that early termination can be performed, or to plan for prenatal and perinatal care if pregnancy continues. ${ }^{3}$ Authors present a case of a thoracoomphalopagus twins diagnosed at 10 weeks of gestation, highlighting the nature of this condition, the ultrasonographic findings and the management of these cases.

\section{CASE REPORT}

A 33-year-old woman, gravida 2 para 1, was referred to our fetal medicine unit at 10 weeks of gestation for suspected conjoined twins after a routine ultrasound examination. Her past medical history was unremarkable, there was no family history of twins and the actual pregnancy was a spontaneous conception. Present ultrasound (US) revealed a monochorionic monoamniotic twin pregnancy with two fetuses in a fixed face-to-face position. 


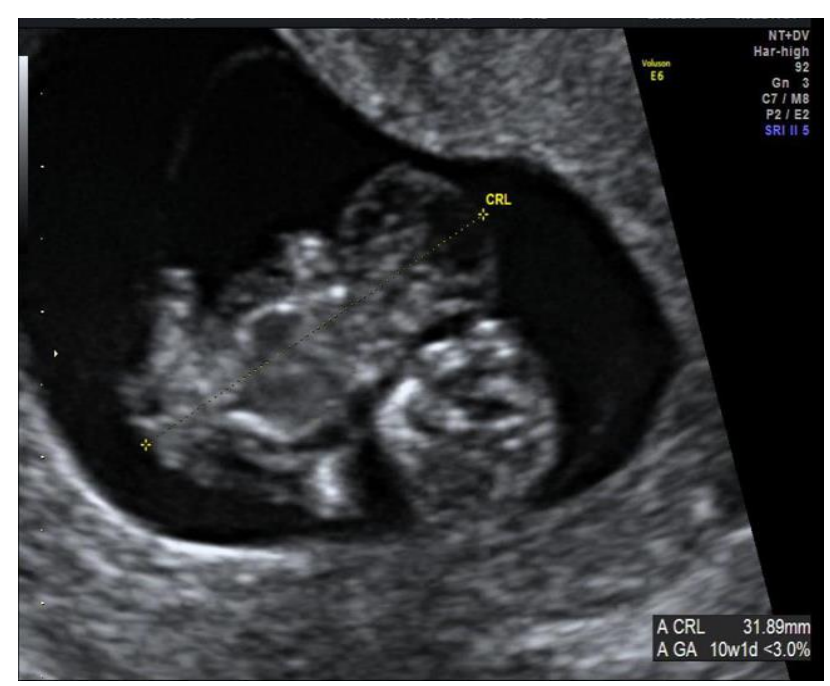

Figure 1: Ultrasound image of thoraco-omphalopagus twins at 10-week gestation.

Two heads were visualized, and two upper and two lower limbs were seen for each fetus. There was no change in the relative positions of the fetuses despite attempts. The twins were found to be joined at the thorax and upper abdomen, and only one fetal heart seemed to be observed. Both fetuses had cystic hygroma (Figure 1 and 2).

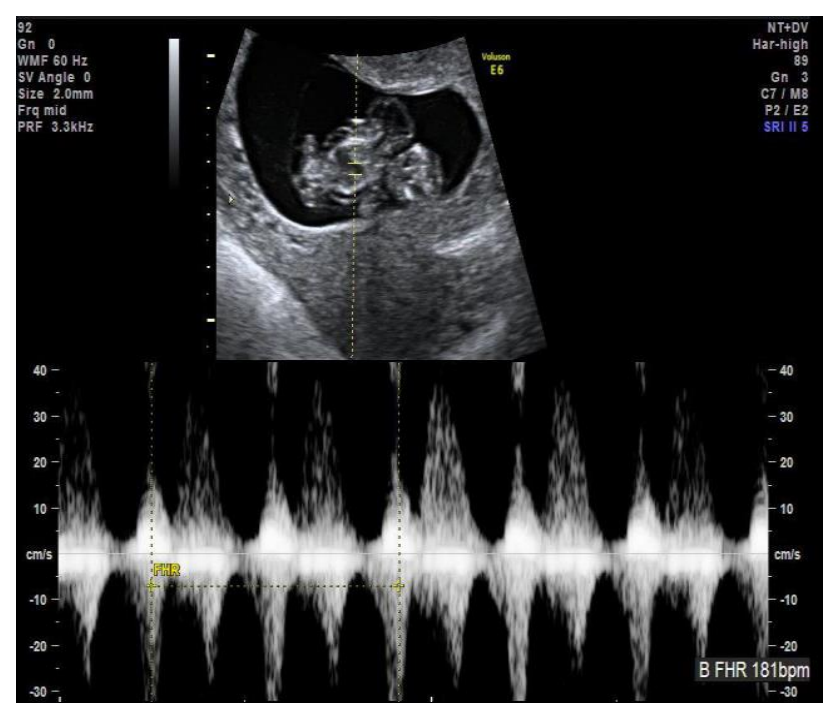

Figure 2: Ultrasound showing a single fetal heart rate.

On the base of these findings, the diagnosis of thoracoompalopagus twins was made. The couple was informed about US findings and counseled on the management options. They opted for termination of pregnancy, which was performed medically within one week. Autopsy confirm the diagnosis: two fetuses fused from the upper thorax to umbilicus. Two hearts were present, but they shared the stomach, liver, pancreas and bowel. Fetus 1 had esophageal atresia and absent right lung and fetus 2 had a complete atrioventricular canal defect. Gonads were not identified (Figure 3). Analysis showed a 46, XX karyotype.
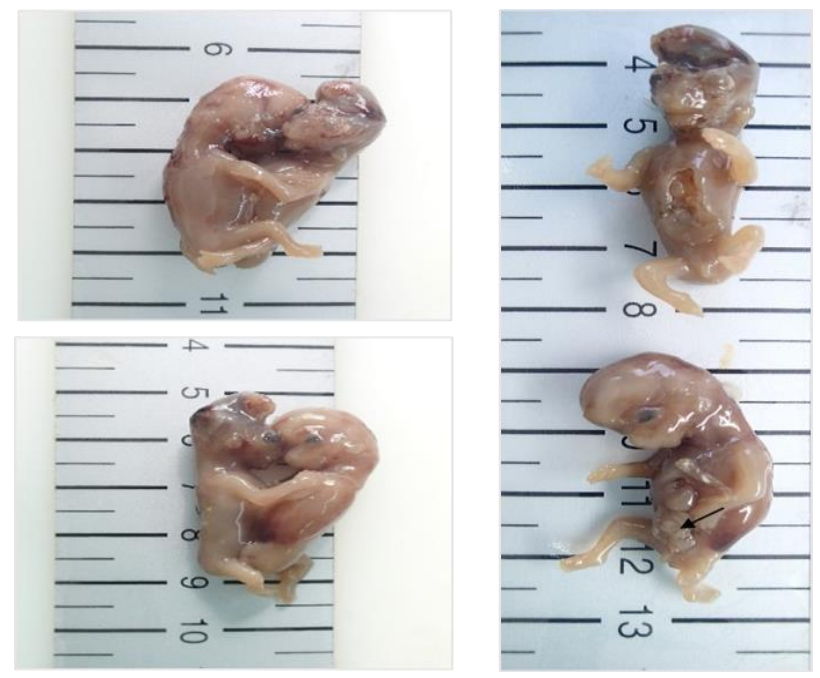

Figure 3: Gross features of thoraco-omphalopagus conjoined twins; notochordal axis as far apart as ventro-ventral, mid-torso, with shared intestinal tract (arrow); two spines and two heads, four upper limbs and four lower limbs and two pelvises.

\section{DISCUSSION}

Conjoined twins are a rare type of monochorionic twins, estimated to occur in 1.5 per 100.000 births worldwide. ${ }^{1-4}$ Etiology is unknown, but there are two different theories that explain the formation of conjoined twins. According to the fission theory, 13-15 days after fertilization, the embryonic disc undergoes an incomplete separation, whereas in the "fusion theory" two separate monoovulatory embryonic discs undergo a secondary association. ${ }^{1,4}$

Female fetuses are more commonly affected with male to female ratio of $1: 3$, particularly in thoracopagus type..$^{5,6}$ Based on the anatomical site of union, conjoined twins are classified as craniopagus (skull), thoracopagus (thorax), omphalopagus (abdomen) ischiopagus (ischia), rachipagus (vertebral column), pygopagus (sacrum) and parapagus (torso). ${ }^{7}$ The most frequent type of all conjoined twins is thoracopagus $(40 \%)$ and the rarest is craniopagus. ${ }^{7}$ Mixed types are also found, like in this case, thoraco-omphalopagus, combining features of two groups, with a reported incidence of $28 \% .^{5}$

Early diagnosis by US is possible in modern day obstetrics. ${ }^{3}$ Suspicious US findings that may suggest the diagnosis include: both fetal heads in the same plane, no change in the relative position after maternal movement and manual manipulation, fetal scoliosis, contiguous skin, unusual limb position and more than three vessels in the cord..$^{3,8-10}$

Associated congenital defects unrelated to the area of fusion are common, as is stillbirth. Three-dimensional US examination, echocardiography, and magnetic resonance images (MRI), may be helpful to determine associated 
anomalies, clarify the anatomy and determine the extent of deformity. ${ }^{6}$ Detailed evaluation is crucial to counsel the parents about prognosis and to prepare for possible postnatal surgical separation.

Surgery to separate conjoined twins may range from relatively simple to extremely complex, depending on the points of fusion and the shared organs. Most cases of separation are extremely risky and life-threatening. ${ }^{1}$ Prognosis is very poor among conjoined twins in general. In all, 40-60\% are stillbirth and among the live births, almost $35 \%$ do not survive beyond 24 hours of life. ${ }^{7}$ The present case focuses on morphological features of an early diagnosis of thoraco-omphalopagus conjoined twins, emphasizing the importance of sonographic assessment in all twin pregnancies.

A shared heart in fetuses is particularly difficult to diagnose, especially in such an early stage of pregnancy. Either a repeat US, echocardiography or MRI could be used to overlap this limitation. Also, fetal autopsy can contribute in understanding normal and abnormal embryogenesis and anatomic classification of conjoined twins according to axis orientation, symmetry and expression.

Funding: No funding sources

Conflict of interest: None declared

Ethical approval: Not required

\section{REFERENCES}

1. Osmanagaoglu MA, Aran T, Guven S, Kart C, Ozdemir O, Bozkaya H. Thoracopagus conjoined twins: a case report. ISRN Obstet Gynecol. 2011;2011:3.

2. Herkiloglu D, Baksu B, Pekin O. Early prenantal diagnosis of thoraco-omphalopagus twins at ten weeks of gestation by ultrasound. Turk J Obstet Gynecol. 2016;13:106-8.

3. Alkhateeb M, Mashaqbeh M, Magableh S, Rafiq H, Quteiba N, Abdelkheleg A. Early Prenatal Diagnosis of thoracopagus twins by ultrasound. Acta Informed Med. 2015;23:60-2.

4. Oksuzoglu A, Moraloglu O, Aktulay A, Yaprak E, Sevki C, Leyla M. Conjoined Twins: a case report of thoraco-omphalopagus. J Ank Univ Fac Med. 2011;64:3.

5. Mishra N, Rohilla M. Thoraco-omphalopagus conjoined twins: a case report and literature review. Gynacol Obstet Case Report. 2015;1:3.

6. Brizot ML, Liao AW, Lopes LM, Okumura M, Marques MS, Krebs V, et al. Conjoined twins pregnancies: experience with 36 cases from a single center. Prenat Diagn. 2011;31:1120-5.

7. Krawczyk J, Borowsky D, Wegrzyn P, Drews K. Siamese twins-prenatal diagnosis in the first trimestre of pregnancy. Case study and review. Ginekol Pol. 2015:86:477-9.

8. Winkler N, Kennedy A, Byrne J, Woodward P. The imaging spectrum of conjoined twins. Ultrasound Quarterly. 2008;24:249-55.

9. Hubinot C, Kollman P, Malvaux V. First trimester diagnosis of conjoined twins. Fetal Diagnosis Ther. 1997;12:185-7.

10. Pajkrt E, Jauniaux E. First-trimester diagnosis of conjoined twins. Prenat Diagn. 2005;25:820-6.

Cite this article as: Cunha SS, Coutada RS, Neiva AR, Nogueira R. Early prenatal diagnosis of conjoined twins: a case report. Int J Reprod Contracept Obstet Gynecol 2018;7:5162-4. 